\title{
Cyclo (Tyrosyl-Prolyl) Produced by Streptomyces sp.: Bioactivity and Molecular Structure Elucidation
}

\author{
ROFIQ SUNARYANTO ${ }^{1,2^{*}}$, BAMBANG MARWOTO², LIESBETINI HARTOTO ${ }^{1}$, \\ ZAINAL ALIM MAS'UD ${ }^{3}$, AND TUN TEDJA IRAWADI ${ }^{3}$ \\ ${ }^{I}$ Department of Agro-Industrial Technology, Institut Pertanian Bogor, Darmaga Campus, Bogor 16680, Indonesia; \\ ${ }^{2}$ Center of Biotechnology, Badan Pengkajian dan Penerapan Teknologi, \\ Kawasan Puspiptek Serpong, Tangerang, Banten 15314, Indonesia; \\ ${ }^{3}$ Department of Chemistry, Institut Pertanian Bogor, Darmaga Campus, Bogor 16680, Indonesia
}

\begin{abstract}
Determination of bioactivity by minimum inhibitory concentration (MIC) methods and molecular structure identification of antibiotic produced by Streptomyces sp. have been carried out. The antibiotic was produced by liquid culture using Streptomyces sp. isolate. Purification of antibiotic was carried out by silica gel column chromatography and preparative HPLC. Molecular structure identification was carried out using ESI-MS, ${ }^{1} \mathrm{H} N M R,{ }^{13} \mathrm{C}$ NMR, and ${ }^{13} \mathrm{C}$ DEPT NMR. Pure antibiotic showed inhibition activity to Gram-negative and Gram-positive bacteria. MIC to Escherichia coli ATCC 25922, Pseudomonas aeruginosa ATCC 27853, Staphylococcus aureus ATCC 25923, and Bacillus subtilis ATCC 66923 were 27.0, 68.7, 80.2, and $73.7 \mu \mathrm{g} \mathrm{mL}^{-1}$, respectively. Identification using ESI-MS showed that the molecular weight of this antibiotic was $260 \mathrm{~g} \mathrm{~mol}^{-1}$, and molecular formula was $\mathrm{C}_{14} \mathrm{H}_{16} \mathrm{~N}_{2} \mathrm{O}_{3}$. Elucidation of molecular structure using ${ }^{1} \mathrm{H} \mathrm{NMR},{ }^{13} \mathrm{C} \mathrm{NMR}$, and ${ }^{13} \mathrm{C}$ DEPT NMR showed that antibiotic was cyclo(tyrosyl-prolyl).
\end{abstract}

Key words: antibiotic, cyclo(tyrosyl-prolyl), inhibitory concentration, bioactivity

Telah dilakukan penentuan bioaktivitas antibiotik menggunakan metode konsentrasi hambatan minimum dan identifikasi struktur molekul antibiotik yang dihasilkan oleh Streptomyces sp. Antibiotik diproduksi dengan menggunakan isolat Streptomyces sp. dengan kaldu fermentasi. Pemurnian antibiotik dilakukan menggunakan kromatografi kolom silika gel dan HPLC preparatif. Identifikasi struktur molekul dilakukan menggunakan ESI-MS, ${ }^{1} \mathrm{H}$ NMR, ${ }^{13} \mathrm{C}$ NMR, dan ${ }^{13} \mathrm{C}$ DEPT NMR. Antibiotik hasil purifikasi menunjukkan daya hambat terhadap bakteri Gram-negatif dan Gram-positif. Konsentrasi hambatan minimum terhadap Escherichia coli ATCC 25922, Pseudomonas aeruginosa ATCC 27853, Staphylococcus aureus ATCC 25923, dan Bacillus subtilis ATCC 66923 masing-masing ialah 27.0, 68.7, 80.2, dan $73.7 \mu \mathrm{g} \mathrm{mL}^{-1}$. Identifikasi menggunakan ESI-MS menunjukkan bobot molekul antibiotik sebesar $260 \mathrm{~g} \mathrm{~mol}^{-1}$, dengan rumus molekul $\mathrm{C}_{14} \mathrm{H}_{16} \mathrm{~N}_{2} \mathrm{O}_{3}$. $\mathrm{Hasil}$ elusidasi struktur molekul menggunakan ${ }^{1} \mathrm{H}$ NMR, ${ }^{13} \mathrm{C}$ NMR, dan ${ }^{13} \mathrm{C}$ DEPT NMR menunjukkan antibiotik yang dihasilkan oleh Streptomyces sp. adalah cyclo (tyrosyl-prolyl).

Kata kunci:antibiotik, siklo (tirosil-prolil), konsentrasi hambatan, bioaktivitas

Increasing microbial resistance due to the use of antibiotics and the emergence of new pathogenic microbes has inspired the search of new antibiotics from microbes. This situation encourages the growing importance of business to get cheap antibiotic materials continuously available in large quantities and has all the elements needed for the manufacture of antibiotics.

Approximately 800 classes of peptide antibiotics have been discovered and studied by several researchers. Most of these peptide antibiotics have been included in clinical trials and has been used in several clinical drugs such as actinomycin, gramicidine, bacitracin, polymyxyn, tyrocidine, and many other peptide antibiotics (Dubin et al. 2005).

Developments in science and inventions peptide antibiotics initiated new drug developments, especially for the treatment of infections (Kesting et al. 2010). The discovery of peptide antibiotics produces broad-

*Corresponding author, Phone/Fax: +62-21-7560208, Email: rofiqsn@yahoo.com spectrum antimicrobial activity with the potential to make peptides as anti-cancer drugs (Lu and Chen 2010) and anti-virus (Lee et al. 2011) or parasite infections (Manfredini et al. 2010). One member of the class of the simplest peptide antibiotics with low molecular weight was cyclo dipeptide group. Although cyclo dipeptide antibiotic have a low molecular weight and simple structure, this antibiotic is known have antimicrobial activity with a broad spectrum (Rhee 2004). For example antibiotics cyclo (leu-pro) has a minimum inhibition concentration (MIC) $32 \mu \mathrm{g} \mathrm{mL}^{-1}$ against Enterococcus faecium 99-38, and the MIC $\mu \mathrm{g} \mathrm{mL}^{-1}$ against $E$. faecalis $\mathrm{K}-01-511$. Cyclo(phe-pro) has a minimum inhibition concentration $\mu \mathrm{g} \mathrm{mL}^{1}$ against $E$. faecium K-99-38. Combination of cyclo(leupro) with cyclo(phe-pro) was able to increase antimicrobial activity, where the MIC against $E$. faecium 99-38 K-1 was $1 \mu \mathrm{g} \mathrm{mL}^{-1}$ and MIC against $E$. faecalis $\mathrm{K}-01-511$ was $0.5 \mu \mathrm{g} \mathrm{mL}^{-1}$ (Rhee 2004). The objective of this research was to obtain information on bioactivity of an antibiotic produced by Streptomyces $\mathrm{sp}$. and elucidate molecular structure of antibiotic. 


\section{MATERIALS AND METHODS}

Microorganism. Streptomyces sp. was isolated from sediment of marine site in Banten West Java (Sunaryanto et al. 2010). The isolate was deposited in strain collection of the Biotechnology of Microbial Culture Collection (Bio-MCC) BPPT Puspiptek Serpong, Tangerang.

Liquid Culture and Extraction of Active Substance. An established slant of isolate was inoculated into a $250 \mathrm{~mL}$ flask containing $100 \mathrm{~mL}$ of vegetative medium (YEME medium) consisting of: bacto peptone $5 \mathrm{~g} \mathrm{~L}^{-1}$, yeast extract $3 \mathrm{~g} \mathrm{~L}^{-1}$, malt extract 3 $\mathrm{g} \mathrm{L}^{-1}$, glucose $3 \mathrm{~g} \mathrm{~L}^{-1}$, demineral water $25 \mathrm{~mL}$, and sea water $75 \mathrm{~mL}$. The $\mathrm{pH}$ value of the medium was adjusted to 7.6 before sterilization. The flask was incubated at $30^{\circ} \mathrm{C}$ for 2 days in an incubator-shaker. Fifty milliliters of the culture was transferred to $1000 \mathrm{~mL}$ of the fermentation medium. Fermentation medium consisted of bacto peptone $15 \mathrm{~g} \mathrm{~L}^{-1}$, yeast extract $3 \mathrm{~g} \mathrm{~L}^{-1}$, Fe (III) citrate hydrate $0.3 \mathrm{~g} \mathrm{~L}^{-1}$, demineralized water $250 \mathrm{~mL}$, and sea water $750 \mathrm{~mL}$ (Nedialkova and Mariana 2005). The $\mathrm{pH}$ value of the medium was adjusted to 7.6 before sterilization. The fermentation was carried out at $30^{\circ} \mathrm{C}$ for 5 days in incubator-shaker.

For extraction of active substance, the culture broth was centrifuged at $14000 \mathrm{x}$ g for $15 \mathrm{~min}$. Biomass was dried and weighed than extracted twice using methanol $500 \mathrm{~mL}$. Methanol extract was concentrated by evaporation under vacuum to the least possible volume, after dehydration with anhydrous $\mathrm{Na}_{2} \mathrm{SO}_{4}$ and weighed. The broth supernatants were extracted using ethyl acetate. Supernatant and the organic solvent were mixed thoroughly by shaking them in $2 \mathrm{~L}$ capacity separating funnel and allowed to stand for $30 \mathrm{~min}$. Two layers were separated; the aqueous layer and the organic layer, which contained the solvent and the antimicrobial agent. The organic layer was concentrated by evaporation under vacuum to the least possible volume, after dehydration with anhydrous $\mathrm{Na}_{2} \mathrm{SO}_{4}$. The aqueous layer was re-extracted and the organic layer added to the above organic layer. The organic layer was concentrated by repeated cycle of evaporation under vacuum.

The dry extract of the supernatant was purified using silica gel column chromatography. Dry extract was injected onto the column and then eluted stepwise with chloroform-methanol solvent system as follows: first the column was eluted with $100 \%$ chloroform (fraction 1). Then repeated with reducing the chloroform by $10 \%$ in each fraction while the methanol was increased by $10 \%$ in each fraction, until the percentage of methanol was $100 \%$. Thirty fractions were collected (each of $20 \mathrm{~mL}$ ) and then concentrated and dried for testing their antimicrobial activities. The active fractions obtained from chromatography column were further purified by preparative HPLC.

Preparative HPLC. Purification by preparative HPLC was conducted using a Waters 2695 HPLC, photodiode array detector (PAD), and column puresil $5 \mu \mathrm{C} 184.6 \times 150 \mathrm{~mm}$. The sample volume was $100 \mathrm{~L}$ per injection under conditions of average pressure of $1267 \mathrm{psi}$, and the flow rate was $1 \mathrm{~mL} \mathrm{~min}^{-1}$ where the mobile phase was $0-45 \%$ methanolwater and time period was $25 \mathrm{~min}$.

Elucidation of Chemical Structure. Molecular weight and formula were determined using ESI-MS (LCT Premier-XE waters), molecular structure elucidation of active compound were determined using FTIR (Shimadzu 8300), ${ }^{1} \mathrm{H}$ NMR, ${ }^{13} \mathrm{C}$ NMR, and DEPT ${ }^{13} \mathrm{CNMR}$ (Buker AV-500 (500 Mhz)).

Antimicrobial Activity Assay. Antimicrobial activity was monitored by the agar diffusion paperdisc $(6 \mathrm{~mm})$ method. Discs were dripped with methanol solution of extract, dried, and then placed over the agar surface plates freshly inoculated with either E. coli ATCC 25922, Staphylococcus aureus ATCC25923, Bacillus subtilis ATCC 66923, and Pseudomones aeruginosa ATCC27853 as test organisms. Suspensions of test organisms were adjusted to $10^{6} \mathrm{CFU} \mathrm{mL}{ }^{-1}$. Each experiment was run in duplicate, and the most potent isolates were noted for each test microorganism, based on the mean diameter of inhibition zones (Bonev et al. 2008). Rifampicin (500 ppm) was used as a control.

Minimum Inhibitory Concentration (MIC). MIC determinations were performed using the agardilution methods according to methods of Andrews (2001) and Bonev et al. (2008). Active purified compound was dissolved in methanol $\left(6500 \mu \mathrm{g} \mathrm{mL}^{-1}\right)$ and taken as standard stock. A series of two fold dilutions each solution were dripped on paper disc 6 $\mathrm{mm}$, dried, then placed over on agar surface plates freshly inoculated with either E. coli ATCC 25922, $S$. aureus ATCC25923, B. subtilis ATCC 66923, or $P$. aeruginosa ATCC27853. Minimum inhibitory concentration is defined as the lowest concentration of antimicrobial that will inhibit the visible growth of a micro-organism and determined toward a standard curve of clearing zone diameter and the concentration of active compound. The MIC of tetracycline and streptomycin as positive controls were also determined and each experiment was run in duplicate.

HPLC Analysis. Analysis was performed using HPLC with an analytical Sunfire C18 column (4.6 x $250 \mathrm{~mm}$, Shiseido Co. Ltd., Tokyo, Japan). Mobile 
phase used methanol-water $(0-100 \%$ linear gradient for $25 \mathrm{~min}$ and then isocratic elution with $100 \%$ methanol over $10 \mathrm{~min}$ ), at a flow rate of $1 \mathrm{~mL} \mathrm{~min}^{-1}$, volume of injection $10 \mu \mathrm{L}$ perinjection, and detection was at a of $210 \mathrm{~nm}$.

\section{RESULTS}

Liquid culture of isolate was carried out for 5 days by using yeast-peptone medium. From a $5 \mathrm{~L}$ volume of culture, $4.72 \mathrm{~g}$ of dry biomass was obtained and after extraction by methanol $2.72 \mathrm{~g}$ of extract was obtained. On the other hand, $0.33 \mathrm{~g}$ of ethyl acetate extract was obtained from supernatant. Antibacterial activity assay of the both extract against $E$. coli ATCC 25922, S. aureus ATCC25923, P. aeruginosa ATCC 27853, B. subtilis ATCC 66923 showed that the extract of supernatant was active, but no activity with the extract of biomass (Table 1).

Supernatant extract was further purified using column chromatography and preparative HPLC. Pure active fraction was collected and MIC was determined using four bacterial testes. The active fraction had a strong inhibition against Gram-positive and Gramnegative (Table 2). MIC of the compound to E. coli ATCC 25922 was $27.0 \mu \mathrm{g} \mathrm{mL}^{-1}$, while to $P$. aeruginosa ATCC 27853 was $68.7 \mu \mathrm{g} \mathrm{mL}^{-1}$. When compared with tetracycline and streptomycin, the active fraction had the highest inhibition against $E$. coli ATCC 25922, but lower inhibitions against $P$. aeruginosa ATCC 2785. Active fraction also had a strong inhibition against Gram-positive bacteria, MIC to $S$. aureus ATCC 25923 was $80.2 \mu \mathrm{g} \mathrm{mL}^{-1}$ while to B. subtilis ATCC 66923 was $73.7 \mu \mathrm{g} \mathrm{mL}^{-1}$. Compared with the tetracycline and streptomycin, this active fraction had higher inhibition against $S$. aureus ATCC 25923 and $B$. subtilis ATCC 6692.

Molecular weight, formula and structure elucidation of active compound were determined using
ESI-MS, ${ }^{1} \mathrm{H}$ NMR, ${ }^{13} \mathrm{C}$ NMR (Fig 1), and FTIR respectively (Fig 4). ESI-MS spectra were obtained on LCT Premier-XE waters. ESI-MS spectra showed that this active compound has molecular weight of $260.0 \mathrm{~g}$ $\mathrm{mol}^{-1}$. Data base from LCT Premier-XE Waters Program showed that this molecule had 14 carbon, 16 hydrogen, 2 nitrogen, and 3 oxygen. The most possible of molecular formula was $\mathrm{C}_{14} \mathrm{H}_{16} \mathrm{~N}_{2} \mathrm{O}_{3}$. The position each carbon, nitrogen, oxygen, and hydrogen atoms were confirmed by ${ }^{1} \mathrm{HNMR},{ }^{13} \mathrm{C}$ NMR, and FTIR. This chemical characteristics were indicated by ESI-MS at $m / z 261(\mathrm{M}+\mathrm{H})^{+}$(Fig 1A).

High-resolution ${ }^{1} \mathrm{H}$ NMR spectrum were obtained on a Bruker AV-500 (500 MHz) with tetramethylsilane (TMS) as internal standard in $\mathrm{CDCL}_{3}$ and give

Table 3 Spectrum data of ${ }^{1} \mathrm{H}$ NMR and ${ }^{13} \mathrm{C}$ NMR of active compound produced by Streptomyces sp.

\begin{tabular}{|c|c|c|c|}
\hline No & $\begin{array}{l}\delta^{13} \mathrm{C} \\
(\mathrm{ppm})\end{array}$ & $\begin{array}{l}\delta^{\mathrm{I}} \mathrm{H}(\mathrm{ppm}) \\
\text { (in } \mathrm{MeOD})\end{array}$ & Functional group \\
\hline 1 & $170.795(\mathrm{~s})$ & - & $\begin{array}{c}-\mathrm{N}-\mathrm{C}-\mathrm{R} \\
1 \\
\mathrm{O}\end{array}$ \\
\hline 2 & & - & \\
\hline 3 & $57.926(d)$ & $4.358(\mathrm{t})$ & $-\mathrm{CH}^{-}$ \\
\hline 4 & $166.935(\mathrm{~s})$ & - & $\begin{array}{c}-\mathrm{N}-\mathrm{C}-\mathrm{R} \\
\mathrm{I} \\
\mathrm{O}\end{array}$ \\
\hline 5 & - & - & - \\
\hline 6 & 60.082 (d) & $4.048(\mathrm{dd})$ & $-{ }_{1}^{-\mathrm{CH}}-$ \\
\hline 7 & $29.421(\mathrm{t})$ & $2.088(\mathrm{~m})$ & $-\mathrm{CH}_{2}-$ \\
\hline 8 & $22.477(\mathrm{t})$ & $1.801(\mathrm{~m})$ & $-\mathrm{CH}_{2}-$ \\
\hline 9 & $45.942(\mathrm{t})$ & $3.518(\mathrm{dd})$ & $-\mathrm{CH}_{2}-\mathrm{N}_{\mathrm{I}}$ \\
\hline 10 & $37.694(\mathrm{t})$ & 3.066 (dd) & $-\mathrm{CH}_{2}-$ \\
\hline 1 ' & $127.651(\mathrm{~s})$ & - & $=C-R$ \\
\hline $2^{\prime}$ & 132.135 (d) & 7.031 (d) & $=\mathrm{CH}-$ \\
\hline $3^{\prime}$ & $116.315(\mathrm{~d})$ & $6.690(d)$ & $=\mathrm{CH}-$ \\
\hline 4 ' & $157.699(\mathrm{~s})$ & & $=\mathrm{C}-\mathrm{OH}$ \\
\hline 5 , & $116.315(d)$ & 6.690 (d) & $=\mathrm{CH}-$ \\
\hline 6 ' & $132.135(\mathrm{~d})$ & $7.031(\mathrm{~d})$ & $=\mathrm{CH}-$ \\
\hline
\end{tabular}

Table 1 Antibacterial activity of biomass and supernatant extract from Streptomyces sp.

\begin{tabular}{lcccc}
\hline & \multicolumn{4}{c}{ Diameter of clear zone (mm) } \\
\cline { 2 - 5 } Samples & $\begin{array}{c}\text { Escherichia coli } \\
\text { ATCC 25922 }\end{array}$ & $\begin{array}{c}\text { Staphylococcus aureus } \\
\text { ATCC 25923 }\end{array}$ & $\begin{array}{c}\text { Bacillus subtilis } \\
\text { ATCC 66923 }\end{array}$ & $\begin{array}{c}\text { Pseudomonas aeruginosa } \\
\text { ATCC 27853 }\end{array}$ \\
\hline Extract of biomass & - & - & - & - \\
Extract of supernatant & 9.55 & 10.39 & 24.43 & 9.64 \\
Control (rifampicin $500 \mathrm{ppm})$ & 10.12 & 21.27 & 44.57 & 10.08 \\
\hline
\end{tabular}

Diameter of disc paper: $6 \mathrm{~mm}$

Table 2 Minimum inhibitory concentration of active purified compound

\begin{tabular}{lccc}
\hline & \multicolumn{2}{c}{ Minimum inhibitory concentration $\mu \mathrm{g} \mathrm{mL} \mathrm{m}^{-1}$} \\
\cline { 2 - 5 } Sample & $\begin{array}{c}\text { Escherichia coli } \\
\text { ATCC 25922 }\end{array}$ & $\begin{array}{c}\text { Staphylococcus aureus } \\
\text { ATCC 25923 }\end{array}$ & $\begin{array}{c}\text { Bacillus subtilis } \\
\text { ATCC 66923 }\end{array}$ \\
\hline Active purified compound & 27.0 & 80.2 & 73.7 \\
Tetracycline (positive control) & 64.0 & 256.0 & 128.0 \\
Streptomycin (positive control) & 50.0 & 130.0 & 120.0 \\
\hline
\end{tabular}




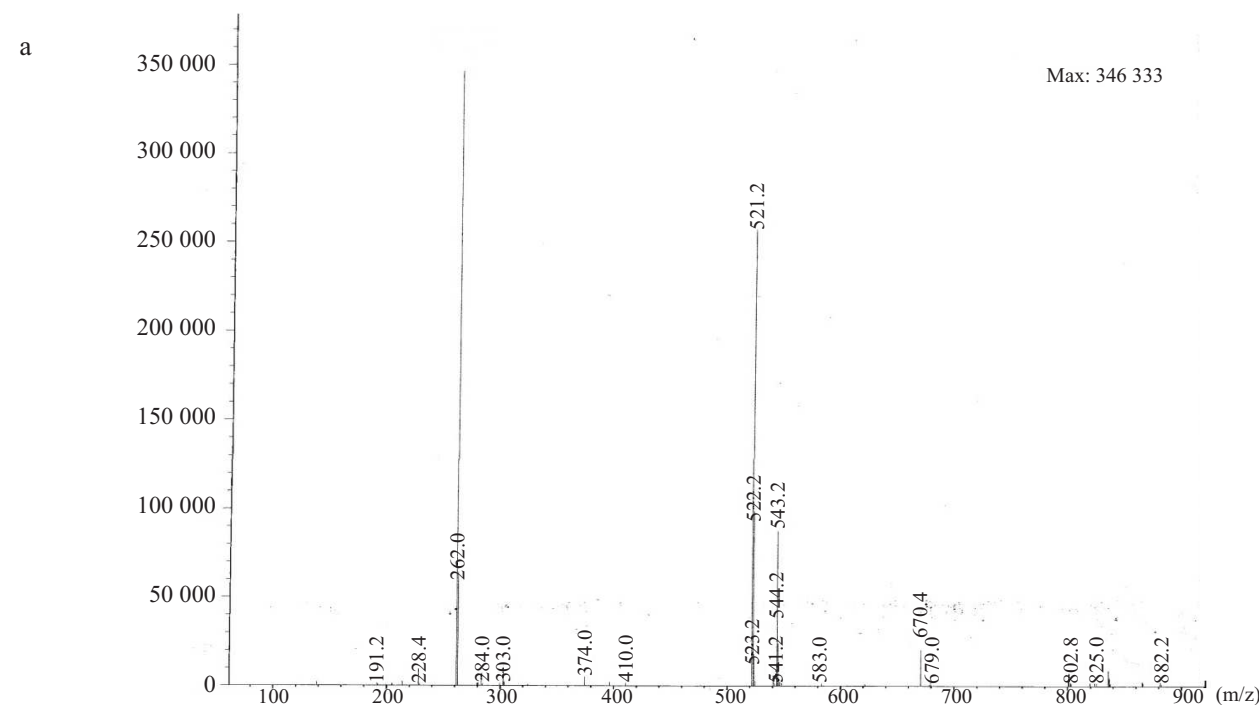

$\mathrm{b}$

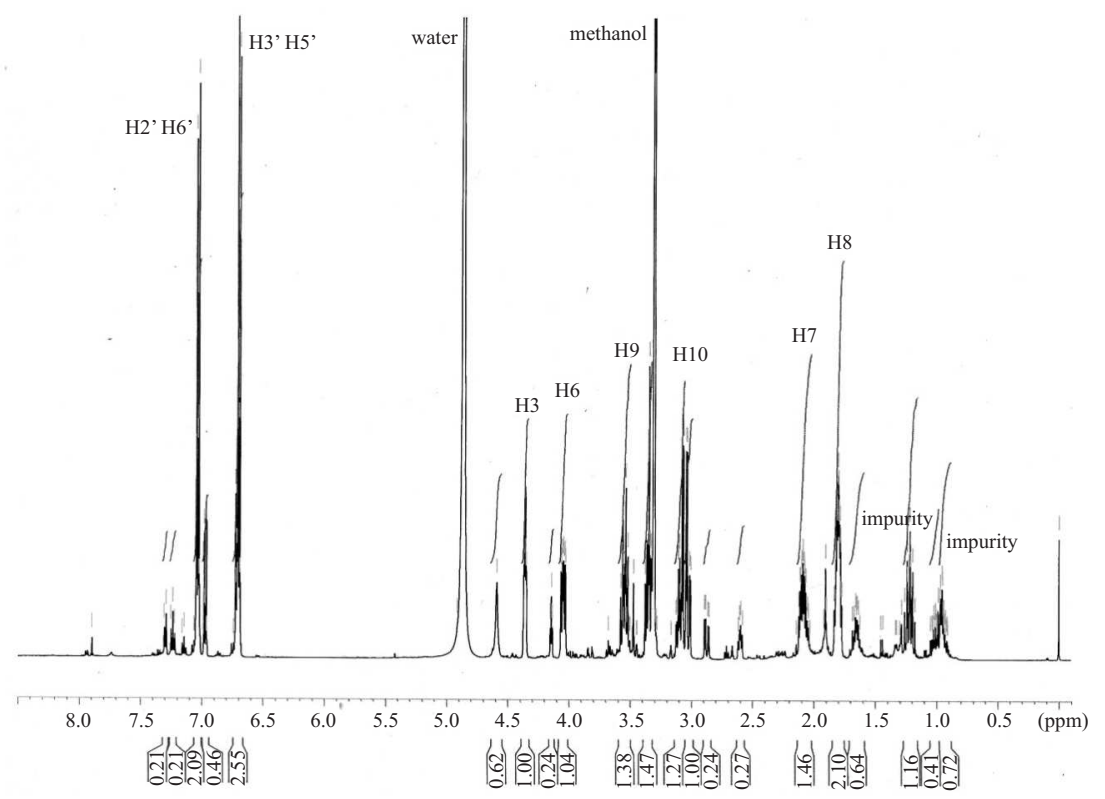

c

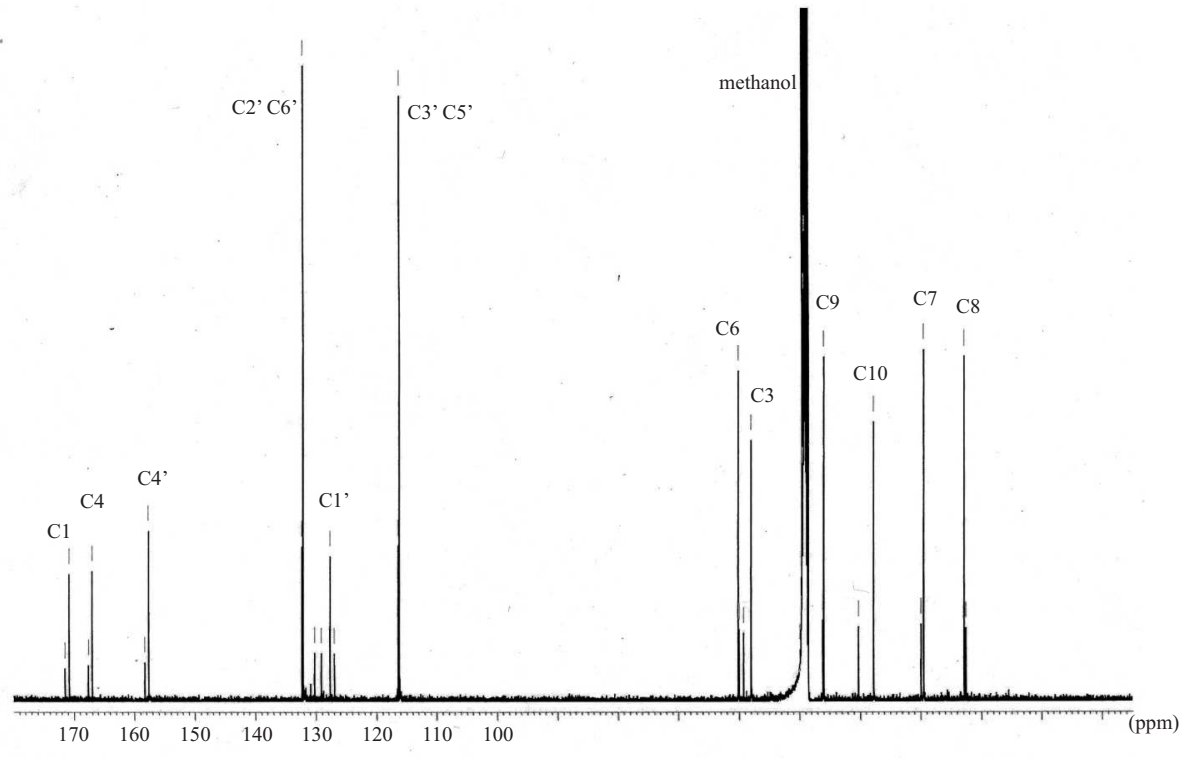

Fig 1 Spectrum of bioactive compound produced by Streptomyces sp.: a, ESI-MS m/z $261(\mathrm{M}+\mathrm{H})^{+} ; \mathrm{b},{ }^{1} \mathrm{H}$ NMR; $\mathrm{c},{ }^{13} \mathrm{C}$ NMR. 
following data: $\delta_{\mathrm{H}}: 4.358(\mathrm{t}, 1 \mathrm{H}), 4.048(1 \mathrm{H}, \mathrm{dd}), 2.088$ $(2 \mathrm{H}, \mathrm{m}), 1.801(2 \mathrm{H}, \mathrm{m}), 3.518(2 \mathrm{H}, \mathrm{dd}), 3.066(2 \mathrm{H}, \mathrm{dd})$, $7.031(2 \mathrm{H}, \mathrm{d}), 6.690(2 \mathrm{H}, \mathrm{d})$, and ${ }^{13} \mathrm{C}$ spectrum : 170.795 (s), 57.926 (d), 166.935 (s), 60.082 (d), 29.421 $(\mathrm{t}), 22.477(\mathrm{t}), 45.942(\mathrm{t}), 37.694(\mathrm{t}), 127.651(\mathrm{~s})$, 132.135 (d), 116.315 (d), 157.699 (s). The impurities of active compound was also showed at ${ }^{1} \mathrm{H} N M R \delta_{\mathrm{H}} 1.7$ $\delta_{\mathrm{H}} 0.9$ (Fig 1B). Based on information of ESI-MS, ${ }^{1} \mathrm{H}$ NMR, and ${ }^{13} \mathrm{C}$ NMR (Fig 3) spectrums the molecular structure of active compound can be predicted as Fig 2. Spectrum data of ${ }^{1} \mathrm{H}$ NMR and ${ }^{13} \mathrm{C} N M R$ were presented on Table 3. Structure elucidation of active compound was also conducted using DEPT ${ }^{13} \mathrm{C}$ NMR (Fig 3).

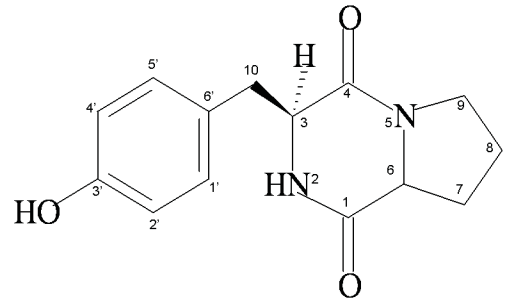

Fig 2 Molecular structure prediction of active compound produced by Streptomyces sp.

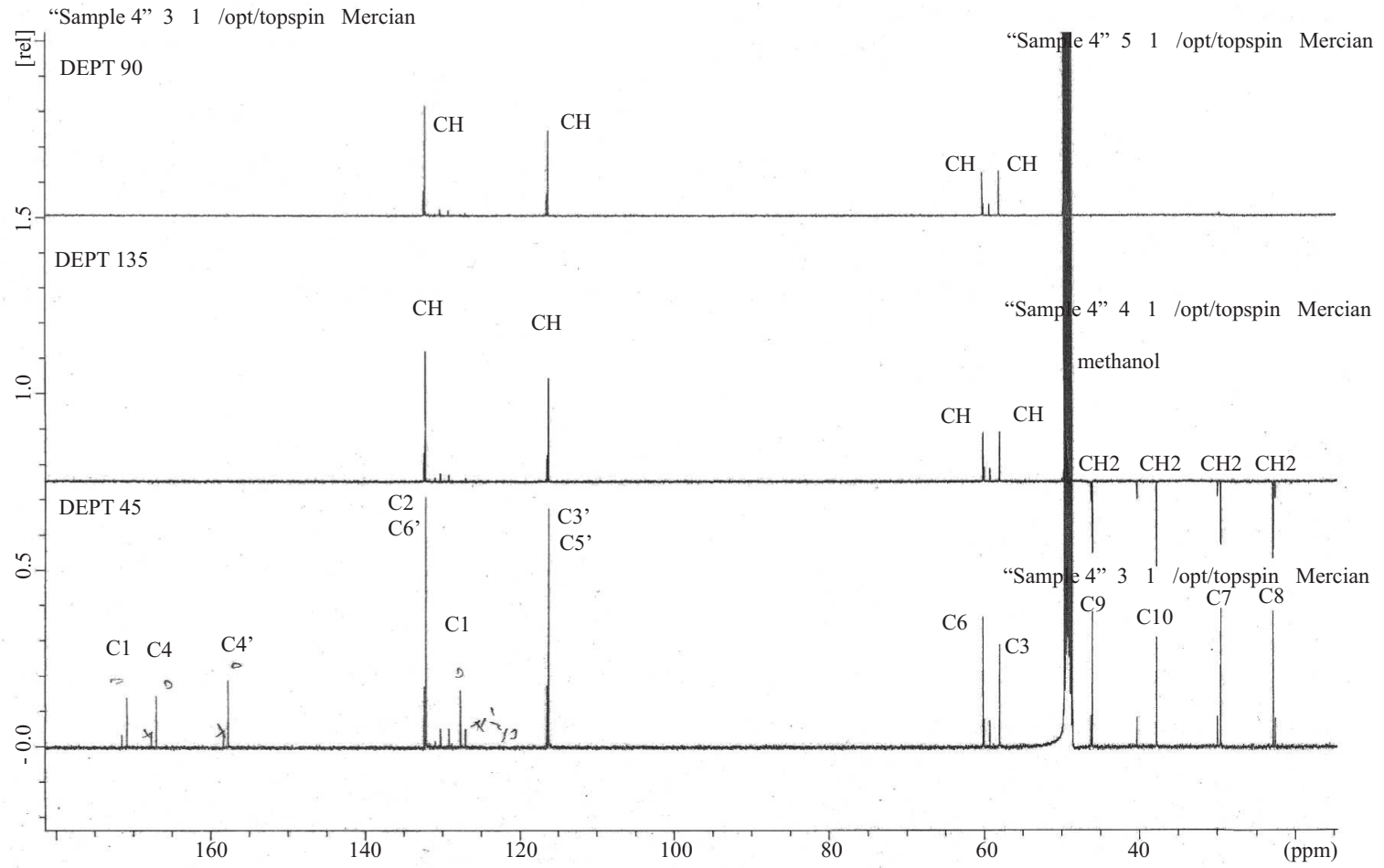

Fig 3 Spectrum of DEPT ${ }^{13} \mathrm{C}$ NMR active compound produced by Streptomyces sp.

The infra red spectrum in a $\mathrm{KBr}$ pellet showed characteristic bands at $3383 \mathrm{~cm}^{-1}(\mathrm{~N}-\mathrm{H}), 3227 \mathrm{~cm}^{-1}(\mathrm{O}-$ H), $2959 \mathrm{~cm}^{-1}$ (saturated C-H), $1660 \mathrm{~cm}^{-1}(\mathrm{C}=\mathrm{O}), 1515$ $\mathrm{cm}^{-1}$ (benzene ring), $1456 \mathrm{~cm}^{-1}$ (methine), $1344 \mathrm{~cm}^{-1}$ (methylene), $1232 \mathrm{~cm}^{-1}$ (phenol), $1116 \mathrm{~cm}^{-1}$ (C-O), 827 $\mathrm{cm}^{-1}$ ( $p$-disubstituted benzene ring) (Fig 4).
Two singlet carbons representing a ketone group were evident in the ${ }^{13} \mathrm{C}$ spectrum at $\delta 170.795$ (s) (C1) and $\delta 166.935$ (s) (C4) (Table 3, Fig 1C). Further analysis of the ${ }^{13} \mathrm{C}$ spectrum revealed two other non substituted carbons $\left[\delta 127.651\left(\mathrm{Cl}^{\prime}\right), 157.699\left(\mathrm{C}^{\prime}\right)\right]$, six methine carbons $[\delta 57.926(\mathrm{C} 3), 60.082$ (C6), 132.135 (C2'), 116.315 (C3'), 116.215 (C5'), 132.135 $\left.\left(\mathrm{C}^{\prime}\right)\right]$, and four methylene carbons $[\delta 29.42(\mathrm{C} 7)$, 22.477 (C8), 45.942 (C9), 37.694 (C10)]. DEPT 45 spectrum on Fig 3 showed that there were 3 nonsubstituted carbon $\left[\delta 127.651\left(\mathrm{C} 1{ }^{\prime}\right), 157.699\left(\mathrm{C}^{\prime}\right)\right.$, and $166.935(\mathrm{C} 4)$ ]. DEPT $135^{\circ}$ and $90^{\circ}$ showed that there were six methine carbons $[\delta 57.926(\mathrm{C} 3), 60.082$ (C6), 132.135 (C2'), 116.315 (C3'), 116.215 (C5'), $\left.132.135\left(\mathrm{C}^{\prime}\right)\right]$ and four methylene carbons $[\delta 29.42$ (C7), 22.477 (C8), 45.942 (C9)]. Carbons at position $3^{\prime}$ and $5^{\prime}$ appeared more upfield than $\mathrm{C}^{\prime}$ and $\mathrm{C} 6$ '. This was due to the shielding effect of the hydroxyl group at $\mathrm{C}^{\prime}$ ' toward its ortho coupled carbon (C3' and $\left.\mathrm{C}^{\prime}\right)$. A similar phenomenon occurred on $\mathrm{C}^{\prime}$ (para coupled with $\mathrm{C}^{\prime}$ ) which shifted more upfield than $\mathrm{C} 2$ ' and $\mathrm{C} 6$ '. 


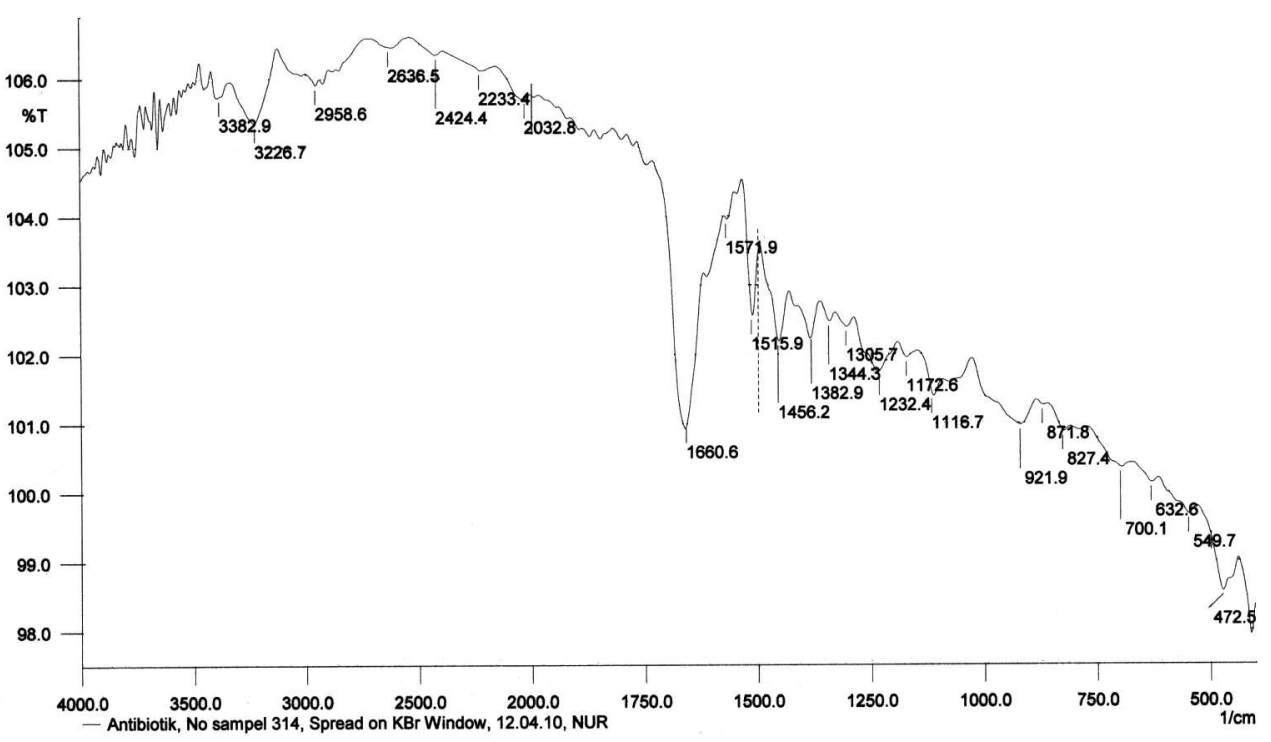

Fig 4 Infra red spectrum of active compound produced by Streptomyces sp.

spectrum activity and also able to act as an anti-viral and anti cancer. The same case were also presented by (Lu and Chen 2010; Lee et al. 2011). In addition to having antimicrobial activity with a broad spectrum, our compound also had lower MIC compared with tetracycline suggesting higher activity than tetracyclin and streptomycin. The same result is shown by Rhee (2004).

Activity of cyclo(tyrosyl-prolyl) on the $P$. aeruginosa is lower compared with tetracycline. It is suspected that the $P$. aeruginosa has a resistance to cyclo(tyrosyl-prolyl). According to Macfarlane et al. (2000) and Reig et al. (2009), P. aeruginosa has a resistance to type of peptide and aminoglycoside antibiotics. Cyclo(tyrosyl-prolyl) was peptide antibiotic and streptomycin was aminoglycoside antibiotic. P. aeruginosa has highly adaptable nature, including the ability to develop resistance. It can grow on a wide variety of substrates and alter its properties in response to changes in the environment (Lambert 2002). Thus, lower inhibition of cyclo(tyrosyl-prolyl) and streptomycin than that of tetracycline on $P$. aeruginosa might be caused by resistance.

This active compound was included in group cyclo dipeptide, namely was cyclo(tyrosyl-prolyl). This active compound has the same profile such as ${ }^{1} \mathrm{H}$ NMR, ${ }^{13} \mathrm{C}$ NMR, Infra red spectrum, and molecular weight with cyclo(tyrosyl-prolyl) that found previously but from different origin (Stierle et al. 1988; Guo et al. 2007). Previously, this compound was produced by Alternaria alternate and can be used as a host-specific phytotoxin for spotted knapweed (Stierle et al. 1988), and produced by $P$. fluorescens GcM5-1A isolated from the pine wood nematode (PWN), and from Bursaphelenchus xylophilus (Guo et al. 2007).

\section{ACKNOWLEDGMENTS}

We thank Hardaning Pranamuda, Anis Mahsunah and Evita Chrisnayani for their valuable advice and support our research, and Mercian Co. Japan for sample analyses using ESI-MS, ${ }^{1} \mathrm{H}$ NMR, ${ }^{13} \mathrm{C}$ NMR, and DEPT ${ }^{13} \mathrm{C}$ NMR. First author was supported by Islamic Development Bank scholarship.

\section{REFERENCES}

Andrews JM. 2001. Determination of minimum inhibitory concentration. J Antimicrob Chemother. 48(Suppl. 1):5-16. doi: 10.1093/jac/48. suppl_1.5.

Bonev B, James H, Judicael P. 2008. Principles of assessing bacterial susceptibility to antibiotics using the agar diffusion method. J Antimicrob Chemother. 61(6):12951301. doi: 10.1093/jac/dkn090.

Dubin AP, Mak, Dubin G, Rzychon M, Stec-Niemczyk J, Wladyka J, Maziarka K, Chmiel D. 2005. New generation of peptide antibiotics. Acta Biochim Pol. 52(3):633-638. doi:10.1093/jac/dkn090.

Guo Q, Daosen G, Zhao B, Xu J, Li R. 2007. Two cyclic dipeptides from Pseudomonas fluorescens GcM5-1A carried by the pine wood nematode and their toxicities to Japanese black pine suspension cells and seedlings in vitro. J Nematol. 39(3):243-247.

Kesting MR, Stoeckelhuber M, Holzle F, Mucke T, Neumann K, Woermann K, Jacobsen F, Steinstraesser L, Wolff KD, Loeffelbein DJ, Rohleder NH. 2010. Expression of antimicrobial peptides in cutaneous infections after skin surgery. Brit J Dermatol. 163(1):121-127. doi: 10.1111/j.1365-2133.2010.09781.x.

Lambert PA. 2002. Mechanisms of antibiotic resistance in Pseudomonas aeruginosa. J R Soc Med. 95(Suppl. 41):22-26.

Lee SB, Li B, Jin S, Daniel H. 2011. Expression and characterization of antimicrobial peptides retrocyclin-101 and protegrin to control viral and bacterial infections. Plant Biotechnol J. 9(1):100-115. doi: 10.1111/j.1467-7652.2010.00538.x.

$\mathrm{Lu} \mathrm{J}$ and Chen Z. 2010. Isolation, characterization and anticancer activity of SK84, a novel glycine-rich antimicrobial peptide from Drosophila virilis. Peptides. 31(1):44-50. doi:10.1016/j.peptides. 2009.09.028.

Macfarlane EMA, Kwasnicka A, Hancock REW. 2000. Role of Pseudomonas aeruginosa PhoP-PhoQ in resistance to antimicrobial cationic peptides and aminoglycosides. Microbiology. 146:25432554 . 
Manfredini F, Beani L, Taormina M, Vannini L. 2010. Parasitic infection protects wasp larvae against a bacterial challenge. Microb Infect. 12(10):727-735. doi:10.1016/j.micinf.2010.05.001.

Milne PJ, Oliver DW, Roos HM. 1992. Cyclodipeptides: Structure and conformation of cyclo(tyrosyl--prolyl). J Crystallog Spect Res. 22(6):643-649. doi: 10.1007/BF01160980.

Munekata M and Tamura G. 1981. Selective inhibition of SV40transformed cell growth by diketopiperazines. Agric Biol Chem. 45: 2618-2628.

Nedialkova D and Mariana N. 2005. Screening the antimicrobial activity of actinomycetes strains isolated from Antartica. J Cult Collect. 4: 29-35.

Reig S, Hutha A, Kalbacherb H, Winfried, Kerna V. 2009. Resistance against antimicrobial peptides is independent of Escherichia coli
AcrAB, Pseudomonas aeruginosa MexAB and Staphylococcus aureus NorA efflux pumps. Int J Antimicrob Agents. 33(2):174-176. doi:10.1016/j.ijantimicag.2008.07.032.

Rhee KH. 2004. Cyclic dipeptides exhibit synergistic, broad spectrum antimicrobial effects and have anti-mutagenic properties. Int $\mathrm{J}$ Antimicrob Agent. 24(5):423-427. doi:10.1016/j.ijantimicag.2004. 05.005 .

Sunaryanto R, Marwoto B, Irawadi TT, Mas'ud ZA, Hartoto L. 2010. Isolation and characterization of antimicrobial substance from marine Streptomyces sp. Microbiol Indones. 4(2):84-89. doi: 10.5454/mi.4.3.1.

Stierle A, Cardellina JH, Strobel GA. 1988. Maculosin, a host-specific phytotoxin for spotted knapweed from Alternaria alternata. Proc Nat Acad Sci. 85(21): 8008-8011. 